\title{
GENDER-BASED HARASSMENT AND THE HOSTILE WORK ENVIRONMENT
}

\section{INTRODUCTION}

Gender discrimination is a pervasive evil that potentially confronts all women who enter the job market. Title VII of the Civil Rights Act of 1964 provides female employees with remedies for gender discrimination affecting the "terms, conditions, or privileges" of their employment. ${ }^{1}$ When an employer discriminates against women with regard to traditional "terms" of employment, such as hiring, firing, and promotion, aggrieved employees may seek a remedy under Title VII by filing disparate treatment or disparate impact claims. ${ }^{2}$ Gender discrimination, however, often affects an altogether different aspect of the employment relationship-the work atmosphere. Courts have recognized that the environment in which an employee works is a protected "term" of employment under Title VII. ${ }^{3}$ Female employees may thus bring what are known as "hostile work environment actions" to remedy gender discrimination that poisons the work atmosphere. ${ }^{4}$

1. Title VII of the Civil Rights Act of $1964, \S 703,42$ U.S.C. $\$ 2000 \mathrm{e}-2$ (1988). Subsection (a) of the statute provides:

It shall be an unlawful employment practice for an employer-(1) to fail or refuse to hire or to discharge any individual, or otherwise to discriminate against any individual with respect to his compensation, terms, conditions, or privileges of employment, because of such individual's race, color, rehigion, sex, or national origin.

Id. $\S 2000 \mathrm{e}-2(\mathrm{a})(1)$.

2. For the standards of proof for a disparate treatment claim, see McDonnell Douglas Corp. v. Green, 411 U.S. 792 (1973) (allegation of racially discriminatory refusal to re-hire a black employee); and Texas Dep't of Community Affairs v. Burdine, 450 U.S. 248 (1981) (allegation of gender discrimination in employer's decision not to proinote and to subsequently terminate fernale employee). For the standards of proof for a disparate impact claim, see Griggs v. Duke Power Co., 401 U.S. 424 (1971) (allegation that high school diplonna requirennent and use of standardized imtelligence test as criteria for hiring and promotion have racially discriminatory impact); Watson v. Fort Worth Bank \& Trust, 487 U.S. 977 (1988) (allegation that use of subjective criteria in promotion decisions has racially discriminatory impact); Wards Cove Packing Co., Inc. v. Atonio, 490 U.S. 642 (1989) (allegation that employer's hiring and promotion policies create racial stratification in work force).

3. See Meritor Sav. Bank v. Vinson, 477 U.S. 57, 65 (1986) ("Title VII affords employees the right to work in an environment free from discriminatory intimidation, ridicule, and insult."); Rogers v. EEOC, 454 F.2d 234, 238 (5th Cir. 1971) ("the phrase 'terms, conditions, or privileges of employment' in Section 703 [codified at 42 U.S.C. $\$ 2000$ e (1988)] is an expansive concept which sweeps within its protective ambit the practice of creating a working environment heavily charged with ethric or racial discrimination."), cert. denied, 406 U.S. 957 (1972). The extent to which the work environment is a protected "term" of employinent is discussed in Part II of this Note.

4. See Meritor, 477 U.S. at 66. See infra text accompanying note 9. The hostile work environment remedy is also available for discrimination based on race, religion, and national origin. See infra note 22. 
"Gender discrimination" is a broad category that encompasses all unequal treatment motivated by an individual's maleness or femaleness. This broad category can be divided into two subsets: (1) actions that stem froin sexual motives; and (2) actions that are based on an individual's gender, but are unrelated to sexual desires. ${ }^{5}$ Although this distinction is central to the following discussion, ${ }^{6}$ it is ultimately irrelevant for purposes of Title VII. Title VII proscribes discrimination "because of... [an] individual's . . . sex"7 and thus facially apphes to all gender-1notivated discrimination. The statute provides protection both from the employer who demands sexual favors as a condition of einployment and from the einployer who refuses to hire women because he beheves they are inferior to inen. ${ }^{8}$

The Supreme Court held in Meritor Savings Bank v. Vinson that "a plaintiff may establish a violation of Title VII by proving that discrimination based on sex has created a hostile or abusive work environment."9 Despite the broad language in Meritor, many lower federal courts have applied a rough distinction between sexually motivated gender discrimination (subset one above) and non-sexually motivated gender discrimination (subset two above) in their treatinent of hostile work environment claims. Lower federal courts have clearly recognized that an employer who creates a hostile work environment by sexually harassing his em-

5. It is possible to hypothesize a third subset, gender discrimination which flows from a mixture of sexual and non-sexual motives, as well as other entirely different modes of dividing the category of gender discrimination. The division presented here is simply a useful construct for analyzing the current judicial treatment of gender discrimination in the work environment.

6. See infra note 12.

7. 42 U.S.C. $\$ 2000$-2(a)(1). Title VII uses the term "sex" in the sense of "gender." See Bundy v. Jackson, 641 F.2d 934, 942 (D.C. Cir. 1981) (proper question in determining whether discrimmation against female employee is based on "sex" is whether discrimination is motivated by her "womanhood"). This Note uses the phrase "gender discrimination" as coextensive with the phrases "discrimination because of sex" and "discrimination based on sex."

8. The former practice, known as quid pro quo sexual harassment, has long been recognized as a violation of Title VII. See Barnes v. Costle, 561 F.2d 983 (D.C. Cir. 1977) (reversing summary judgment for employer who attempted to abohish female employee's position after she refused demands for sexual favors); Equal Employment Opportumity Commission Guidelines on Discrimination Because of Sex, 29 C.F.R. $\S 1604.11$ (a) (1988) [hereinafter EEOC Guidelines] (requirement that an employee submit to sexual favors as a condition of employment constitutes sexual harassment in violation of Title VII). The latter practice, of course, also violates the statute. See Bell v. Crackin Good Bakers, Inc., 777 F.2d 1497, 1500 (11th Cir. 1985) (reversing summary judgment for employer who failed to promote female employee and engaged in scheme to force her resignation where supervisor indicated that "if it was left up to him he would never have any women employees ..."); Bell v. Birmingham Linen Serv., 715 F.2d 1552 (11th Cir. 1983) (reversing summary judgment for employer who declined to promote a female employee where evidence shows decision may have been the result of a supervisor's attempt to keep women from attaining that position), cert. denied, 467 U.S. 1204 (1984).

9. 477 U.S. 57, 66 (1980) (emphasis added). 
ployees violates Title VII. ${ }^{10}$ These courts, however, have not recognized with similar clarity that an employer who poisons the work atmosphere by engaging in gender-based harassment unrelated to sexual desires also violates the statute.

The allegations at issue in Meritor exemplify the type of sexually motivated conduct that lower federal courts consider actionable under Title VII. In Meritor, Mechelle Vimson, an assistant branch manager with Meritor Savings Bank, alleged that Sidney Taylor, the manager of the office where she worked, subjected her to a three-year pattern of sexual harassment and sexual abuse. Taylor allegedly propositioned Vinson soon after she began working at the bank and then made repeated demands for sexual favors. Vimson testified that she acquiesced in these demands for fear of losimg her job and estimated that she had intercourse with Taylor between forty and fifty times over a three-year period. In addition, Vinson alleged that Taylor publicly fondled her, exposed himself to her, and even forcibly raped her. ${ }^{11}$

Sexual harassment of the type alleged in Meritor obviously constitutes an extremely serious offense, but sexual harassment is only a part of the larger spectrum of gender discrimination that affects the work environment. Female employees also face a broad range of harassment that is motivated by gender but not by sexual desires. Thus, unwarranted criticism, rudeness, ridicule, insults, and epitliets directed at woinen in the workplace may not be sexually motivated, but may nonetheless flow from a gender-based animus. For ease of reference, this Note calls liarassment that is motivated by gender, but is unrelated to sexual desires, "gender-based harassment." 12

Although gender-based harassment is as capable of creating abusive working conditions as sexual harassment, it occupies a tenuous position in the courts. Dwyer v. Smith ${ }^{13}$ illustrates the uncertain status of allegations of gender-based harassment. In Dwyer, a female pohice officer alleged that her co-workers and supervisors engaged im and tolerated a pattern of abusive conduct that created a hostile work environment. The

10. Indeed, the lower federal courts preceded the Supreme Court in recognizing such a cause of action. See Katz v. Dole, 709 F.2d 251 (4th Cir. 1983); Henson v. City of Dundee, 682 F.2d 897 (11th Cir. 1982); Bundy v. Jackson, 641 F.2d 934. See infra notes 51-51.

11. Meritor, 477 U.S. at 60 .

12. Although the use of this phrase is a necessary construct for analyzing the current judicial treatment of gender discrimmation in the workplace, this Note takes the position that Title VII admits of no distinction between "sexual harassment" and "gender-based harassment." In addition, note that the phrase "gender-based harassment" is not coextensive with the phrase "gender discrimination." Gender discrimination refers to a broader range of conduct which includes actions motivated by sexual desires.

13. 867 F.2d 184 (4th Cir. 1989). 
officer, Stephanie Dwyer, contended that her fellow officers referred to women in degrading terms and that her supervisor subjected her to humiliatimg treatment. She also alleged that fellow officers placed pornographic material in her stationhouse mailbox and questioned her about what she had received, accused her of having sexual relationships with other officers, engaged in gratuitous conversations about sex crimes and sexual behavior, and drove by her home to ascertain whether she had male visitors. ${ }^{14}$ Although these latter acts obviously contained sexual overtones, they do not appear to have been motivated by sexual desires.

The Fourth Circuit affirmed the district court's conclusion that Dwyer had not inade out "a prima facie claim of sexual harassment."15 Her failure to allege that she was the victim of sexually motivated conduct was fatal to her case. The Fourth Circuit noted that during an internal affairs imvestigation, Dwyer "did not contend ... that [her supervisor] engaged in any suggestive behavior-only that he treated her like a 'problem child." "16 The court of appeals also viewed as significant the district court's finding that "no sexual language was ever directed at Dwyer."17 It is not clear whether either the district court or the Fourth Circuit viewed Dwyer's allegations of gender-based harassment as actionable under Title VII. For instance, the district court stated that "perhaps on occasion there has been inappropriate language and inappropriate references made to sex, but not harassment." 18

The thesis of this Note is the relatively simple proposition that all forms of gender discrimination that affect an employee's work environment are potentially actionable under Title VII without regard to whether they arise from sexual inotives. For purposes of Title VII, it is entirely irrelevant that Stephanie Dwyer failed to state a claim of "sexual harassment" or that she did not allege either "suggestive behavior" or "sexual language." Dwyer contended that her employer engaged in a pattern of harassment against her because she was a woman and that this pattern of harassment created a hostile work environinent. She thus alleged that discrimination "because of . . . sex" affected a "term" of her

14. Id. at 188.

15. Id. (emphasis added).

16. Id. (emphasis added).

17. Id. (emphasis added). The district court's statement indicates a flaw in its analysis of Dwyer's claim. Existing precedent has established that an employer's "failure to direct intentionally any discriminatory treatment toward [an employee] is simply not material to the finding of an unlawful employment practice." Rogers v. EEOC, 454 F.2d 234, 239 (5th Cir. 1971) (optometrists' practice of segregating patients on the basis of national origin creates hostile work environment for Hispanic employee).

18. Dwyer, 867 F.2d at 188. The Fourth Circuit held that this finding was not clearly erroneous. Id. at 189. 
employment. These allegations are the only two requisites of a Title VII violation; the statute imposes no additional requirement that a plaintiff allege sexually motivated discrimination.

If the "inappropriate language" and "inappropriate references made to sex" in Dwyer were directed at the plaintiff because of her gender, then they were potentially actionable under Title VII. Dwyer was not necessarily entitled to a remedy under the statute, but she was entitled to have a court evaluate whether the conduct she coinplained of created a hostile work environment. It is far froin clear whether the district court or the Fourth Circuit considered Dwyer's allegations of gender-based harassment. Both opimions focused primarily on the existence of sexual harassment, making it impossible to discern definitively whether or how seriously either court weighed Dwyer's allegations of gender-based harassinent.

Dwyer thus illustrates a significant problem present in current hostile work environment jurisprudence: A judicial focus on sexual harassment has obscured the availability and reduced the effectiveness of Title VII as a remedy for gender-based harassment. Many courts view egregious sexual harassinent of the type at issue in Meritor and other leading hostile work environment cases as the paradigm of a Title VII violation. Conduct that falls short of that mark is not viewed as a significant intrusion on an employee's working conditions. To be sure, courts have not exphcitly drawn a distinction between sexual harassment and genderbased harassment, but hostile work environment actions are rarely successful if an employee does not allege either sexually motivated behavior-typically propositions, advances, or physical touchings-or conduct of a "sexual nature."19

A second problem exists in the current judicial treatınent of gender discrimination in the work environment: Even those courts which recognize that gender discrimination is actionable without regard to the presence of a sexual motive have indicated that employees possess a cause of

19. The phrase "conduct of a sexual nature" is derived from the EEOC Guidelines, 29 C.F.R. $\S 1604.11$ (a) (1988). As noted supra text accompanying note 9, the distinction courts draw between sexually motivated gender discrimination and non-sexually motivated gender discrimination is a rougl one. For many courts, conduct which merely lias a sexual content is actionable under Title VII. Thus, while in Dwyer allegations of harassment merely possessing sexual overtones were insufficient to state a violation of the statute, other courts liave found the existence of a lostile work environment where an employer uses epitliets with sexual connotations or permits pictorial displays of nude women in the workplace. Katz v. Dole, 709 F.2d 251 (4tl Cir. 1983) (hostile work environment exists where female air traffic controller's workplace pervaded by sexual slur, insult, and innuendo and degrading and vulgar sexual epitliets directed to lier). 
action for "sexual harassment."20 Such statements may confuse employees regarding the scope of Title VII's protection by suggesting that they must allege sexually motivated conduct to secure a remedy under the statute. Thus, even substantively correct decisions may obscure the availability of Title VII as a remedy for non-sexually motivated gender discrimination im the workplace.

All acts of gender discrimination have the potential to create abusive working conditions, not just those motivated by sexual desires. Although the presence of an obviously sexual motive makes it easier to estabhish that acts of harassment are based on gender, there is no justification for requiring employees to allege such behavior in order to secure a remedy under Title VII. To the extent that courts apply either an articulated or unarticulated distimction between sexual harassment and gender-based harassment, they restrict the scope of Title VII's protection. Courts should eliminate any such distmction and explicitly recognize that all forms of gender discrimination may serve as a viable predicate for hostile work environment actions. Courts should construe Title VII to provide a remedy for the entire spectrum of unequal treatment suffered by women im the workplace.

Part II of this Note examines the principles underlying the hostile work environment action and the apphication of those principles to gender discrimination in the workplace. Part II(A) begins by discussing the early development of the hostile work environment action in the context of racial, ethnic, and rehgious discrimination. This section argues that the creation of a hostile work environment by an employer is actionable because a protected "term" of employment, the work atmosphere, has been poisoned on the basis of an impermissible criterion. Part II(B) demonstrates that the extension of the hostile work environment to the gender discrimination context was based on recognition of the "terin of employment" principle-not on the sexual nature of the conduct involved in the leading cases in the area. Part II(C) argues that genderbased harassment can meet the criteria for an actionable hostile work environment. Overall, Part II establishes that the theoretical underpinnimgs of the hostile work environment action provide no basis for liniting the remedy to sexual harassment.

Part III examines the current judicial treatment of gender-based harassment. Part III(A) discusses decisions that do not explicitly recog. nize that non-sexual as well as sexual forns of gender discrimination are actionable under Title VII. This section argues that many courts focus

20. See Hall v. Gus Construction Co., 842 F.2d 1010, 1013 (8th Cir. 1988); Hicks v. Gates Rubber Co., 833 F.2d 1406, 1408 (10th Cir. 1987); McKinney v. Dole, 765 F.2d 1129, 1131 (D.C. Cir. 1985) ("sex discrimination/sexual harassment claim"). 
on sexual harassment as paradigmatic of a Title VII violation and thus undervalue claims of gender-based harassment. Part III(B) discusses decisions that have recognized that all forms of gender discrimination are actionable under Title VII without regard to whether they are sexually motivated. This section, however, notes an unfortunate lack of clarity in these opinions. Part IV concludes with a discussion of the ramifications of recognizing gender-based harassment as a predicate for hostile work environment claims.

\section{Underlying Principles of the Hostile Work ENVIRONMENT ACTION AND APPLICATION OF THOSE Principles to GeNDER Discrimination in the WORK ENVIRONMENT}

\section{A. Development of the Hostile Work Environment Action}

1. Judicial Recognition. The hostile work environment action originated in the context of claims of racial, ethnic, and rehgious discrimination in the workplace. Beginning with Rogers v. EEOC, 21 a number of lower federal courts recognized that an employer who creates a work environment rife with racial, ethnic, or religious discrimination violates Title VII. ${ }^{22}$ Although these courts did not use uniform terminology in describing the cause of action they recognized, the essence of each claim was the same: An employer had subjected an employee to abusive or offensive working conditions through discrimination based on an inipermissible criterion.

In Rogers, an Hispanic employee charged that the optometrists for whom she worked discriminated agamst her by segregating their patients on the basis of national origin. ${ }^{23}$ Although the treatment at issue appeared to be directed primarily at the patients, the court found that the effect of the segregation policy on the employee was relevant under Title

21. 454 F.2d 234 (5th Cir. 1971), cert. denied, 406 U.S. 957 (1972).

22. See Firefighters Institute for Racial Equality v. City of St. Louis, 549 F.2d 506, 515 (8th Cir.) (city fire department's practice of excluding blacks from informal "supper clubs" violates duty under Title VII "to provide a nondiscriminatory working environment"), cert denied sub. nom. Barta v. United States, 434 U.S. 819 (1977); United States v. City of Buffalo, 457 F. Supp. 612, 632635 (W.D.N.Y. 1978) (pattern of racial harassment in city's police and fire departments violates Title VII); Conıpston v. Borden, Inc., 424 F. Supp. 157, 160-61 (S.D. Ohio 1976) (constant harassment and verbal abuse of Jewish employee by supervisor violates Title VII); Calcote v. Texas Educ. Found., Inc., 458 F. Supp. 231, 237 (W.D. Tex. 1976) (black supervisor's racial harassment of white employee creates nitolerable working conditions in violation of Title VII), aff'd, 578 F.2d 95 (5th Cir. 1978).

23. Rogers, 454 F.2d at 236. The factual record in the case is rather vague, but the employee, Josephine Chavez, apparently alleged that her employers "classified" their patients in sonie discriminatory fashion. Id. at 238. 
VII. ${ }^{24}$ Judge Goldberg concluded that "the relationship between an employee and his [or her] working environment is of such significance as to be entitled to statutory protection."2s

Judge Goldberg's conclusion represented a significant expansion of existing Title VII caselaw. Prior to Rogers, most Title VII claims imvolved traditional "terms" of employment such as hiring, firing, and promotion-aspects of the employment relationship that have tangible economic effects on employees. ${ }^{26}$ The dissent's contention in Rogers that the segregation policy was a "business practice" and not an "employment practice" subject to Title VII typifies the prevailing view of the statute. ${ }^{27}$ Judge Goldberg, however, took a broad view of the "terms and conditions" language of Title VII.

The fundamental proposition of the decision in Rogers, and the underlying premise of the hostile work environment action, is that an employee's work atmosphere constitutes a protected "term" or "condition" of employment under Title VII. Thus, Judge Goldberg stated, "the phrase 'terms, conditions, or privileges of employment' in Section 703 [now section 2000e-2(a)] is an expansive concept which sweeps within its protective ambit the practice of creating a working environment heavily charged with ethnic or racial discrimination."28 This interpretation of the "terms and conditions" language of Title VII was initially followed

24. The court considered it possible that the policy was "a subtle scheme designed to create a working environment imbued with discrimination and directed ultimately at minority group employees." Id. at 239. Without resolving the issue of whether the policy was directed at Chavez, the court determined that the optometrists" "failure to direct intentionally any discriminatory treatment toward Mrs. Chavez is simply not material to the finding of an unlawful employment practice." Id. The court's reasoning was based upon Griggs v. Duke Power Co., 401 U.S. 424 (1971), whicl Judge Goldberg viewed as establishing that "tlie absence of discriminatory intent by an employer does not redeem an otherwise unlawful employment practice, . . . the thrust of Title VII's proscriptions is aimed at the consequences or effects of an employment practice and not at the employer's motivation." Rogers, 454 F.2d at 239.

25. Rogers, 454 F.2d at 237-38.

26. Judge Goldberg argued that restricting Title VII to traditional economic terms of employment was inappropriate:

Time was when employment discrimination tended to be viewed as a series of isolated and distinguishable events, manifesting itself, for example, in an employer's practices of liring, firing, and promoting. But today einployment discrimination is a far more complex and pervasive phenomenon, as the nuances and subtleties of discriminatory einployment practices are no longer confined to bread and butter issues. As wages and hours of employment take subordinate roles in managenent-labor relationships, the modern employee makes ever-increasing deinands in the nature of intangible fringe benefits. Recognizing the importance of these benefits, we slould neither ignore tlieir need for protection, nor blind ourselves to their potential misuse.

Id. at 238.

27. Id. at 245 (Roney, J., dissenting).

28. Id. at 238 . 
by lower federal courts ${ }^{29}$ and was ultimately validated by the Supreme Court in Patterson v. McLean Credit Union. ${ }^{30}$

The rationale underlying Judge Goldberg's view that the work environment is a protected "term" of employment under Title VII is that "employees' psychological as well as econormic fringes are statutorily entitled to protection from employer abuse."31 The Rogers court explained that "[a]s wages and hours of employment take subordinate roles in management-labor relationships, the modern employee makes ever-increasing demands in the nature of intangible fringe benefits. Recognizing the importance of these benefits, we should neither ignore their need for protection, nor blind ourselves to their potential misuse."32 The "work environment" as a "terun" of employinent for Title VII purposes can be loosely defined as a composite of the physical setting and personal relationships within a workplace. These elements affect an employee's psychological well-being rather than the economic benefits he or she receives from the employment relationship.

Judge Goldberg justified the extension of Title VII to protect employees' psychological well-being on the basis of a broad view of congressional imtent. He beheved the statute was intended to protect noneconomic aspects of the employinent relationship and argned, "One can readily envision working environments so heavily polluted with discrimination as to destroy completely the emotional and psychological stability of minority group workers, ... Section [2000e-2(a)(1)] of Title VII was aimed at the eradication of such noxious practices." 33

29. See United States v. City of Buffalo, 457 F. Supp. 612, 631 (W.D.N.Y. 1978) ("a variety of enployment practices which are related not to economic fringe benefits but to intangibles, such as psychological impact upon minority einployees from a work euvironment heavily charged with discrimination, fall within the protection of the expansive statutory language"); Calcote v. Texas Educ. Found., Inc., 458 F. Supp. 231, 237 (W.D. Tex. 1976) ("Racial harassnent that [leads] to an en1ployec's resignation would appear to give rise to a valid claim . . . under an expansive reading of the prohibition against discrimination because of race in the "terms, conditions, or privileges of enuployment." "); see also Friend v. Leidinger, 588 F.2d 61, 68 (4th Cir. 1978) (Butzner, J., dissenting) ("Congress adopted the language concerning terns, conditions, or privileges of employment to assure that Title VII would reach more than hiring, promotion, and firing. . . . '[T]his language forbids such conduct as the practice of supervisors calling black employees 'Nigger,' of the employers' tolerating ethuic jokes, and of enuployers' requiring that black employees be addressed in less respectful terms than white [employees]" ") (quoting CARson, 3 Employment Discrimination \$ 84.10 (1977)).

30. 491 U.S. 164, 180 (1989) ("Racial harassment in the course of employment is actionable under Title VIT's prohibition against discrimination in the 'terms, conditions, or privileges of employment" ").

31. Rogers, 454 F.2d at 238.

32. Id.

33. Id. 
The Supreme Court validated this broad view of congressional intent in Meritor Savings Bank v. Vinson. ${ }^{34}$ In that case, the Court explicitly rejected the defendant's contention that in passing Title VII, "Congress was concerned with ... 'tangible loss' of an 'economic character,' not 'purely psychological aspects of the workplace environment.' "35

\section{Conduct Actionable Under a Hostile Work Environment Claim.} The mitial decisions recognizing the hostile work environment action stand for the general proposition that a pattern of racial, ethnic, or religious harassment by an employer violates Title VII. ${ }^{36}$ The incidents of harassinent involved in those cases fit into three general categories: (1) unwarranted criticisin of einployees; (2) efforts to ridicule or humiliate einployees; and (3) the use of discriminatory epithets. Thus, in Lucero $v$. Beth Israel Hospital and Geriatric Center, a black supervisor's "almost continuous criticism of the work of the plaintiffs and other non-blacks" coupled with racial slurs and other abusive conduct violated Title VII. ${ }^{37}$ And in Compston v. Borden, Inc., when a supervisor "embark[ed] upon a course of conduct calculated to demean an employee before his fellows because of the employee's professed religious views," the statute also was violated. ${ }^{38}$ Finally, the Eighth Circuit recognized in Cariddi v. Kansas

34. 477 U.S. 57 (1986).

35. Id. at 64 (quoting Brief for Petitioner at 30-31, 34). Justice Rehnquist's opinion in Meritor identified two sources of authority for the proposition that non-economic aspects of the employment relationship are protected by Title VII-the language of the statute and the Equal Employment Opportunity Commission's (EEOC) interpretation of that language.

Justice Rehnquist initially noted that section 2000e-2(a)(1) of Title VII is not by its terms restricted to either "econounic" or "tangible" discrimination. Id. at 64. He then concluded that the phrase "terms, conditions, or privileges of einployment" indicates Congress' intent to " 'strike at the entire spectrum of disparate treatinent of inen and woinen' in employinent." Id. (quoting Sprogis $v$. United Air Lines, Inc., 444 F.2d 1194, 1198 (7th Cir.) cert. denied, 404 U.S. 991 (1971)).

The EEOC Guidelines comprised a second basis of support for the proposition that "harassment leading to noneconomic injury can violate Title VII." Id. at 65 . The Guidelines state the EEOC's conclusion that sexual harassment which "has the purpose or effect of unreasonably interfering with an individual's work performance or creating an intiunidating, hostile, or offensive working environment," 29 C.F.R. $\$ 1604.11$ (a)(3), is actionable "whether or not it is directly linked to the grant or denial of an economic quid pro quo." Meritor, 477 U.S. at 65.

36. See Lucero v. Beth Israel Hosp. and Geriatric Center, 479 F. Supp. 452, 454 (D. Colo. 1979) (black supervisor's continual harassment of non-black employees violates Title VII); United States v. City of Buffalo, 457 F. Supp. 612, 632-35 (W.D.N.Y. 1978) (widespread and egregious racial harassment of blacks in city's police and fire departinents violates Title VII); Compston v. Bordeu, Inc., 424 F. Supp. 157, 159 (S.D. Ohio 1976) (supervisor's constant harassinent and verbal abuse of Jewish employee violates Title VII); Calcote v. Texas Educ. Found., Inc., 458 F. Supp. 231, 237 (W.D. Tex. 1976) (racial harassment of white employee by black supervisor severe enough to cause employee to resign violates Title VII); see also Patterson v. McLean Credit Union, 491 U.S. 164, 180 ("Racial harassinent in the course of employment is actionable under Title VII's prohibition against discrimination in the 'terms, conditions, or privileges of employinent.' ").

37. 479 F. Supp. 452,454 (D. Colo. 1979).

38. 424 F. Supp. 157,160 (S.D. Ohio 1976). 
City Chiefs Football Club, Inc., that "derogatory comments [based on national origin] could be so excessive and opprobrious as to constitute an unlawful employment practice under Title VII."39

The conduct at issue in Calcote v. Texas Educational Foundation, Inc. ${ }^{40}$ presented a pattern of racial harassment. In Calcote, a white residential counselor at a Job Corps Center alleged that a black supervisor subjected him to persistent discriminatory treatment. The counselor, Herman Calcote, contended that his supervisor, Ras Dancy, "tried to frustrate and to harass [him]."41 Calcote introduced the testimony of a former employee that Dancy often "tried to cut down white people."42 Calcote further alleged that Dancy ridiculed his efforts to help a fellow employee in a job-related inatter, filed a deficiency report on him, talked down to him, and "frustrate[d] him at every opportunity." 43 The court held that the Job Corps Center had violated Title VII by permitting Calcote to be subjected to racial harassinent. ${ }^{44}$

The court's reasoning in Calcote, as in other early cases dealing with claims of discrimination in the workplace, appears to have been relatively simple. First, the court found that Dancy's treatment of Calcote constituted "racial harassment." 45 It reached this conclusion on the basis of evidence, primarily consisting of testimony by the plaintiff and a former employee, that Dancy harassed white einployees but not black einployees. ${ }^{46}$ The court then concluded that the pattern of abuse suffered by Calcote had a significant detrimental impact on his work environmentindeed, the harassinent in that case "made [his] working conditions so intolerable that [he was] forced to resign." 47 These two conclusions sustained a finding of a Title VII violation.

3. Limits of the Hostile Work Environment Action. The foregoing discussion demonstrates that the hostile work environinent action poten-

39. 568 F.2d 87, 88 (8th Cir. 1977); see also City of Buffalo, 457 F. Supp. at 635 (racial slurs); Compston, 424 F. Supp. at 158 (epithets based on religion).

40. 458 F. Supp. 231 (W.D. Tex. 1976).

41. Id. at 235.

42. Id.

43. Id. at 237.

44. Id.

45. Id.

46. Id.

47. Id. The court concluded that the Job Corps center had "constructively discharged" Calcote. Id. at 238. Although the constructive discharge of an employee has a tangible, economic impact on that employee, it is ultimately the product of forces aeting on an employee's psyclological well-being. Thus, constructive discharge claims are well-suited to analysis as hostile work environment actions. 
tially proscribes an extremely wide range of employer conduct. ${ }^{48}$ However, although the courts that mitially recognized this action viewed Title VII as providing protection for an employee's psychological well-being, they did not view such protection as absolute. Judge Goldberg articulated the following limit on the hostile work environment action in Rogers: "[A]n employer's mere utterance of an ethnic or racial epithet which engenders offensive feelings in an employee" would not violate the statute. ${ }^{49}$ In addition, the cases above all involved persistent discriminatory treatinent by employers, not isolated incidents.

Judge Goldberg's statement and the fact patterns of the early hostile work environment cases indicate that the hostile work environment action is intended to remedy only serious injuries to an eniployee's psychological well-being. Conduct that is not sufficiently intrusive upon an enployee's psyche is not actionable. Thus, while a pattern of racial or ethnic epithets might be actionable, the isolated utterance of a discriminatory slur is not. For example, in Cariddi, a supervisor's occasional references to Italian-American employees as "dagos" and "Mafia" were insufficient to violate Title VII. ${ }^{50}$

The early cases recognizing the hostile work environment action establish two requisites for proof of a Title VII violation. First, the treatinent complamed of must be based upon a proscribed criterion. This requirement is mandated by the language of Title VII, which prohibits discrimination "because of [an] individual's race, color, religion, sex, or national origin." Second, the discriminatory treatinent alleged must produce a significant detrimental impact on an employee's working conditions. All harassment predicated upon race, rehion, sex, or national origin carries the potential to wound an employee's psyche. Proof of improperly motivated conduct, however, is by itself insufficient to state a

48. In Rogers, Judge Goldberg turned to the language of Title VII to justify the application of the statute to a broad range of employer conduct. He concluded that the decision not to define the term "discrimmation" with specificity manifested a "Congressional intention to define discrimination in the broadest possible terms. Congress chose neither to enumerate specific discriminatory practices, nor to elucidate in extenso the parameter of such nefarious activities." Rogers v. EEOC, 454 F.2d 234, 238 (5th Cir. 1971). Judge Goldberg also relied on the purposes of the statute as a source of authority for giving Title VII an expansive scope. He argued that "Title VII . . . should be accorded a liberal interpretation in order to effectuate the purpose of Congress to eliminatc the inconvenience, unfairness, and humiliation of ethnic discrimination." Id.

49. Id. at 238. However, Judge Goldberg was obviously "not willing to hold that a discriminatory atmosphere could under no set of circumstances ever constitute an unlawful employment practice." Id.

50. 568 F.2d 87, 87 (8th Cir. 1977). See also Friend v. Leidinger, 588 F.2d 61 (4th Cir. 1978) (finding that isolated incidents of racial harassment established by black firefighters did not violate Title VII). 
violation of Title VII. An employee must further demonstrate that such conduct has poisoned his or her work environment.

\section{B. Extension of the Hostile Work Environment Action to Claims of Gender Discrimination in the Workplace}

1. Leading Cases Involve Egregious Sexual Harassment. Gender discrimination, as well as racial and ethnic discrimination, can obviously poison an employee's working conditions. The first cases to charge that gender discrimination in the workplace had created a hostile work environment were sexual harassment suits brought by female employees against their employers. In Bundy v. Jackson ${ }^{51}$ and Henson v. City of Dundee, ${ }^{52}$ the D.C. Circuit and the Eleventh Circuit, respectively, held that an employee possesses a cause of action under Title VII for a hostile work environment created by sexual harassment. The Supreme Court subsequently affirmed the validity of this cause of action in Meritor Savings Bank v. Vinson. 53

Meritor, Bundy, and Henson, the leading cases on gender discrimination in the work environment, all involved egregious acts of harassment that were clearly sexually motivated. ${ }^{54}$ In Meritor, as detailed above, ${ }^{55}$ the plaintiff alleged that her supervisor subjected her to a threeyear pattern of sexual abuse. In Bundy v. Jackson, a female vocational rehabilitation specialist at the District of Columbia Departinent of Corrections alleged that sexual harassment by her supervisors and co-workers created a hostile work environment. ${ }^{56}$ The plaintiff, Sandra Bundy, claimed that both her first-line and second-line supervisors repeatedly propositioned her, both requesting that she join them for sexual haisons. ${ }^{57}$ When Bundy complained about this conduct to a higher level supervisor, he allegedly told her that, "any man in his right mind would want to rape you," 58 and then himself requested that she engage in a sexual relationship with him. ${ }^{59}$ The district court entered findings of fact that " the making of improper sexual advances to female employees

51. 641 F.2d 934 (D.C. Cir. 1981).

52. 682 F.2d 897 (11th Cir. 1982).

53. 477 U.S. 57 (1986). See supra text accompanying note 9.

54. Katz v. Dole, 709 F.2d 251 (4th Cir. 1983), another leading case on gender discrimination in the work environment, involved both sexually-motivated behavior and conduct of a sexual nature. See supra note 19.

55. See supra text accompanying note 11.

56. She also alleged an instance of quid pro quo harassment, supra note 8, contending that she was denied promotions on the basis of her rejection of sexual advances by her supervisors. Bundy $\mathbf{v}$. Jackson, 641 F.2d 934, 938 (D.C. Cir. 1981).

57. Id. at 940 .

58. Id. (quoting district court Finding of Fact No. 37, Appendix to Appellant's Brief at 14).

59. Id. (citing district court Finding of Fact No. 36, Appendix to Appellant's Brief at 14). 
[was] standard operating procedure, a fact of life, a normal condition of einployment," 60 in Bundy's office and that "sexual intimidation was [also] a 'normal condition of employment' "61 for her. ${ }^{62}$

Henson v. City of Dundee also involved allegations of egregious sexual harassment in the workplace. ${ }^{63}$ In Henson, a female police dispatcher claimed that the chief of police subjected her to "numerous harangues of demeaning sexual inquiries and vulgarities" over the two years she was enployed at the department.64 The plaintiff also alleged that the pohice chief made repeated requests for sexual favors during this period. ${ }^{65}$

2. Leading Decisions Based on Principles Developed in Early Hostile Work Environment Cases. Rogers and other cases recognized that the creation of a hostile work environment by an employer violates Title VII for two reasons: (1) the employer has engaged in discrimination on the basis of a proscribed criterion; (2) this discrimination has had a significant detrimental impact on a protected term of employnent, the work atmosphere. 66 The cause of action recognized in Bundy, Henson, and Meritor, was based on these primciples, not on the sexual nature of the conduct involved in those cases. The reasoning of each of these decisions parallels that of Judge Goldberg's opinion in Rogers and reflects a primary concern with the effect of sexual harassinent on an employee's working conditions-not with the evils of sexual harassinent per se.

The D.C. Circuit's decision in Bundy demonstrates the influence of the primciples established im prior hostile work environment caselaw. In his opinion in Bundy, Judge Skelly Wriglit first turned to the question of whether the plaintiff was discriminated against on the basis of a proscribed criterion. He noted that in determining whether a plaintiff lias been discriminated against "because of sex" within the meaming of Title VII, "the question is one of but-for causation: would the complaining

60. Id. at 939 (quoting Finding of Fact No. 38, Appellant's Appendix at 15).

61. Id.

62. Nevertheless, the district court refused to grant relief to Bundy because it concluded that sexual harassment was not discrimination with respect to the "terms, conditions, or privileges" of einployment. Id. at 939.

63. 682 F.2d 897, 899-900 (11th Cir. 1982). In addition to a hostile work environinent claim, the plaintiff brought claims of constructive discliarge and quid pro quo sexual harassment. She alleged that the chief of police prevented her from attending the local police acadeny because of her refusal to submit to his sexual advances.

64. Id. at 899. The plaintiff contended that the chief of police forced her and a co-worker to endure "crude and vulgar language, almost daily inquiring of these two women einployees as to their sexual habits and proclivities." Id. at 900-01.

65. $I d$.

66. See supra text accompanying note $\mathbf{5 0 .}$ 
employee have suffered the harassment had he or she been of a different gender?"67 "But for" causation, however, does not require that gender be the sole factor behind an employer's behavior: "[D]iscrimination is sex discrimination whenever sex is for no legitimate reason a substantial factor in the discrimination."68 Because Bundy's supervisors did not subject male employees to the same treatment she endured, the court had "no difficulty inferring that Bundy suffered discrimination on the basis of sex."69

Finding the existence of an impermissible motive, Judge Skelly Wright next turned to the issue of whether the work environment constitutes a protected "term" of employment under Title VII. He stated:

What remains is the novel question whether the sexual harassment of the sort Bundy suffered amounted by itself to sex discrimination with respect to the "terms, conditions, or privileges of employment." Though no court has as yet so held, we beheve that an affirmative answer follows ineluctably from numerous cases finding Title VII violations where an employer created or condoned a substantially discriminatory work environment, regardless of whether the complaining employees lost any tangible job benefits as the result of the discrimination. ${ }^{70}$

Judge Skelly Wright's opinion in Bundy quotes Judge Goldberg's opinion in Rogers at length and cites much of the existing hostile work environment caselaw. ${ }^{71}$

The decision in Bundy reflects a recognition that sexual harassment that creates a hostile work environment is actionable because of its im-

67. Bundy, 641 F.2d at 942 n.7 (citing Barnes v. Costle, 561 F.2d 983, 900 n.55 (D.C.Cir. 1977)); see also Henson, 682 F.2d at 904 (proof of a hostile work environment claim requires the plaintiff to show that "but for the fact of her sex, she would not have been the object of harassinent"). In Barnes, the D.C. Circuit concluded that a male supervisor made sexual dennands of a feinale employee that he did not make of male employees. Barnes, 561 F.2d at 988 . The Bundy Court noted, "But for her womanhood, ... [Barnes'] participation in sexual activity would never have been solicited." Bundy, 641 F.2d at 942. (quoting Barnes, 561 F.2d at 990) (emphasis added by Bundy court) (footnotes omitted).

68. Bundy, 641 F.2d at 942 .

69. Id. at 943 . The Eleventh Circuit noted in Henson that sexual harassment generally facially constitutes discrimination "because of sex":

In the typical case in which a male supervisor makes sexual overtures to a fenale worker, it is obvious that the supervisor did not treat inale einployees in a similar fashion. It will therefore be a simple inatter for the plaintiff to prove that but for her sex, she would not have been subjected to sexual harassinent.

682 F.2d at 904 (citation omitted).

70. Bundy, 641 F.2d at 943-44. The Eleventh Circuit quoted this language in Henson. 682 F.2d at 902 .

71. Bundy, 641 F.2d at 944-45. See also Meritor Sav. Bank v. Vinson, 477 U.S. 57, 65-66 (1986) (quoting Rogers and endorsing the Equal Employment Opportumity Commission's application of existing hostile work environment caselaw im the context of race, religion, and national origin to harassment based on sex); Henson, 682 F.2d at 901 (citing Rogers and other hostile work environment cases). 
pact on the psychological well-being of female employees, a protected "term" of employment. Judge Skelly Wright argued that Title VII proscribes sexual harassment because it "injects the most demeaning sexual stereotypes into the general work environment and ... always represents an intentional assault on an individual's innermost privacy."72 In addition, the Eleventh Circuit in Henson reasoned:

Sexual harassment which creates a hostile or offensive environment for members of one sex is every bit the arbitrary barrier to sexual equality at the workplace that racial harassment is to racial equality. Surely, a requirement that a man or,woman run a gauntlet of sexual abuse in return for the privilege of being allowed to work and make a living can be as demeaning and disconcerting as the harshest of racial epithets. ${ }^{73}$

The implication of these statements is that sexual harassment is actionable because in damaging an einployee's psyche it intrudes on a protected aspect of the einployinent relationship. The discussion below further demonstrates that employees ouly have a remedy for sexual harassment when it produces a significant effect on their working conditions.

3. A New Limit on Hostile Work Environment Actions: The "Severe or Pervasive" Requirement. The first cases to recognize the hostile work environment claim, as noted above, limited the availability of the action to conduct by an employer that had a significant detrimental impact on an employee's working conditions. ${ }^{74}$ This limit, although clearly apparent from Judge Goldberg's "mere utterance" statement" and the fact patterns of the early cases in this area, was quite nebulous. Henson contributed significantly to the development of the hostile work environinent action by articulating a new standard for evaluating whether discrimination by an einployer had produced a significant enough impact on an employee's working conditions to be actionable under Title VII. The Eleventh Circuit stated, "For sexual harassinent to state a claim under Title VII, it must be sufficiently pervasive so as to alter the conditions of employment and create an abusive working environment."76 Justice Rehnquist adopted this standard in his opinion in Meritor, restating it shightly: "For sexual harassment to be actionable, it must be sufficiently severe or pervasive 'to alter the conditions of [the victin's] employment and create an abusive working environment." "77 The articulation of the

72. Bundy, 641 F.2d at 945 . Indeed, Bundy testified that the sexual harassment by her supervisors caused her serious emotional harm. Id. at 942.

73. Henson, 682 F.2d at 902.

74. See supra text accompanying note 49 .

75. See id.

76. Henson, 682 F.2d at 904.

77. Meritor Sav. Bank v. Vinson, 477 U.S. 57, 67 (1986) (quoting Henson, 682 F.2d at 904). The Henson-Meritor articulation of the limit on hostile work environment actions represents a subtle 
"severe and pervasive" standard by the Eleventh Circuit and the Supreme Court confirms that the core function of the hostile work environment action is to protect an employee's working conditions. Despite the affront to individual dignity inherent in sexual harassment, such conduct is not actionable per se. Absent "severe and pervasive" harassment that alters the conditions of employment, an employee has no remedy for sexual harassment.

Many courts have failed to realize that the action recognized in Bundy, Henson, and Meritor affords specific protection to an employee's work environment. Courts tend to focus primarily on the question of whether an employee has been victimized by sexual harassment. ${ }^{78}$ Such an analysis misconceives the cause of action recognized in these cases. These decisions recognize an action "for" the creation of a hostile work environment on the basis of sexual harassment, not an action "for" sexual harassment per se. The difference is real rather than semantic. The rationale of Meritor and the decisions that came before it is that an employee has a remedy for all impermissibly motivated discrimination that poisons the work environment. These decisions thus do not stand for the proposition that the hostile work environment action is limited to sexual harassment.

\section{Gender-Based Harassment and the Requirements for an Actionable Hostile Work Environment}

Courts have yet to hold clearly and uniformly that a pattern of gender-based harassment alone constitutes a sufficient predicate for a hostile work environment action. ${ }^{79}$ Suppose a male employer constantly criticizes the personalities, opinions, and work of female employees, but not

shift from Rogers. Rogers viewed the work environment itself as a protected "term" of employment. See supra text accompanying note 28. Discrimination "with respect to" the work environment was proscribed by Title VII if it rose to a certain level. See supra text accompanying note 49 . In Meritor, however, Justice Rehnquist stated, "[A]s the courts in both Rogers and Henson recognized, not all workplace conduct that may be described as 'harassment' affects a 'term, condition, or privilege' of employment within the meaning of Title VII." Meritor, 477 U.S. at 67. At least as far as Rogers is concerned, this statement appears to be shightly inaccurate-under the Rogers analysis de minimis harassment would affect a "term" of employment, the work environment, but would not be sufficiently significant to violate Title VII. Justice Rehnquist's approach appears to indicate that only harassment which is "severe or pervasive" enough to itself become a "condition" of employment is actionable under the statute.

Whether this shift is of any practical significance is unclear. It is possible, however, that a requirement that a plaintiff prove that discrimination is itself a "condition" of employment will prove inore difficult to meet than a simple requirement that discrimination be "severe or pervasive."

78. See Dwyer v. Smith, 867 F.2d 184 (4th Cir. 1989), discussed supra text accompanying note 13.

79. See H. KAY, SeX-BASEd Discrimination 535 (1988) (Asking, "Can a plaintiff establish a hostile environment sexual harassment claim in the absence of overt sexual advances?"). 
those of male employees; he regularly behittles women with comments such as "you can't do half the job men can" and "you should stay in the kitchen," and repeatedly uses derogatory epithets such as "bitch" in referring to female employees, but never touches or propositions any female employee. Is such an employer even potentially liable under Title VII? The answer, according to the principles underlying the hostile work environment action, is yes. The absence of a sexual notive is not equivalent to the absence of either (1) discrimination "because of sex" or (2) harassment so "severe or pervasive as to alter the conditions" of employment.

1. Discrimination "Because of Sex." The proposition that discrimination by an employer may be motivated by gender, but not by sexual desires is an obvious one. In the hypothetical above, for example, the employer's behavior may be accounted for by either fervent chauvinism or misogyny. The real difficulty for employees who face such treatment is to prove that an employer's behavior is motivated by gender. Although determining the motivations behind an employer's behavior is certainly difficult, it is not impossible and it is a task in which courts must engage. Title VII proscribes discrimination "because of sex"-courts have no authority to limit the reach of the statute to discrimination "because of sexual desires." 80

The D.C. Circuit in McKinney v. Dole ${ }^{81}$ found it appropriate to evaluate the motives behind a "physically aggressive but not explicitly sexual act by a male supervisor against a female employee" 82 under the "but for" causation test described above. ${ }^{83}$ In McKinney, a budget analyst for the Federal Aviation Administration brought a claim of sex discrimmation alleging that her second-line supervisor had verbally abused her, exposed himself to her, fondled her, and requested sexual favors from her. In addition, she contended that in a dispute over an impending furlough, the supervisor grabbed her arm and twisted it in an effort to prevent her from leaving her office. ${ }^{84}$ The plaintiff alleged that she suffered physical injury from this confrontation. ${ }^{85}$

80. The "because of sex"/sexual problem does not appear with regard to discrimination based on factors other than gender. The problem in the gender area arises at least partially because the term "sexual" has a meaning other than "relating to gender;" it can also mean "relating to crotic desires." This problem does not arise, for example, in the context of the terms "race" and "racial."

81. 765 F.2d 1129 (D.C. Cir. 1985)

82. Id. at 1131.

83. See supra text accompanying note 67 .

84. McKinney, 765 F.2d at 1132.

85. Id. 
The D.C. Circuit focused on whether this incident could constitute part of a pattern of discrimination based on sex. The district court had granted summary judgment for the defendant, assuming that "an incident of physical force toward an employee by a supervisor cannot constitute sexual discrimination or harassinent unless it is for the purpose of obtaining sexual favors or is otherwise blatantly sexually oriented." 86 The D.C. Circuit reversed, holding that "any harassment or other unequal treatinent of an employee or group of employees that would not occur but for the sex of the employee or employees may, if sufficiently patterned or pervasive, coinprise an illegal condition of employment under Title VII."87

In the context of sexual harassment, the "but for" test can generally be applied by asking whether einployers who inake sexual advances toward women also make sucl advances toward men. ${ }^{88}$ Where harassment by an employer is not overtly sexual, however, difficulties arise with this mode of analysis. Courts can certainly ask whether an employer who criticizes and behttles woinen also subjects men to the saine treatment. However, conduct sucli as that engaged in by the hypothetical employer above may flow from motivations other than gender. The employer simply may dislike a particular employee or the employee's job performance may warrant criticism.

Much of Title VII jurisprudence is devoted to determining the real motivations of employers in such circumstances. When employees allege that illegal discrimination has motivated a liiring, firing, or promotion decision, courts apply a system of shifting burdens of production to determine the factual question of whether the employer acted on the basis of a proscribed criterion. This system, developed in McDonnell Douglas Corp. v. Green, requires the plaintiff to establish a prima facie case of discrimination by showing "(i) that he belongs to a racial [or other protected] minority; (ii) that lie applied and was qualifled for a job for wlich the employer was seeking applicants; (iii) that, despite his qualifications, lie was rejected; and (iv) that, after his rejection, the position reinained open and the employer contimued to seek applicants from persons of complainant's qualifications." 89 The prima facie case raises an inference

86. Id. at 1138. Despite the court's use of the phrase "sexual discrimination or harassment," it is clear that Judge Skelly Wright was referring to discrimination "because of sex" in the sense of gender. See id. (quoting Title VII's "because of ... sex" language); see also infra text accompanying note 98.

87. McKinney, 765 F.2d at 1138 (emphasis added).

88. See supra note 69.

89. 411 U.S. 792, 802 (1973). 
of unlawful discrimination by the employer..$^{90}$ The employer may rebut this inference by articulating a "legitimate, nondiscriminatory reason" for the decision at issue. ${ }^{91}$ Finally, the plaimtiff has the opportunity to prove that the articulated reasons were not the "true reasons [for the decision], but were a pretext for discrimination."92

Courts could apply some version of the McDonnell Douglas test to determine whether harassment by an employer that affects an employee's work environment as opposed to the economic conditions of her employment is based on gender. Whatever the precise test applied, the more important point is that employees must be afforded the opportunity to prove that harassment that is not overtly sexual is nonetheless motivated by gender. As the D.C. Circuit noted in McKinney,

[P]roving that a pattern of physical force is illegally discriminatory might be significantly more difficult than proving that a pattern of explicitly sexual advances is illegally discriminatory because the latter are more obviously caused by the sex of the employee. That, however, is simply an evidentiary problem going to one factual component of discrimination."93

In the context of employment decisions affecting tangible economic benefits, courts impose no requirement that a decision be sexually motivated before an employee may secure a Title VII remedy. They should not do so in the context of allegations of gender discrimination affecting the work environment.

Analogies from the race discrimination context also support this view. Employees alleging that they have been discriminated against on the basis of race are not demied an opportunity to seek a remedy simply because ascertaining an employer's notives is difficult. Thus, in Calcote v. Texas Educational Foundation, Inc., ${ }^{94}$ the plaintiff alleged that a pattern of harassment that affected his work environment was based on race. Despite the employer's ability to articulate a nondiscrimmatory reason for the treatınent-it clained that the supervisor perpetrating the harassinent was critical of all employees regardless of their race ${ }^{95}$ - the court was able to conclude that the conduct in question was racially moti-

90. See Furnco Constr. Co. v. Waters, 438 U.S. 567, 577 (1978) (the prima facie case "raises an inference of discrimination only because we presume these acts, if otherwise unexplained, are more likely than not based on the consideration of impermissible factors"); Texas Dep't of Community Affairs v. Burdine, 450 U.S. 248, 254 (1981).

91. McDonnell Douglas Corp., 411 U.S. at 802.

92. Texas Dep't of Community Affairs, 450 U.S. at 253 (citation omitted). The burden of proof of impermissibly motivated discrimination remains at all times with the plaintiff. Id.

93. 765 F.2d 1129, 1139 n.21 (D.C. Cir. 1985).

94. 458 F. Supp. 231 (W.D. Texas 1976). See supra text accompanying notes 40-47.

95. Id. at 235 . 
vated. ${ }^{96}$ Ennployees who allege that they have been discriminated against on the basis of gender rather than race should have the saine opportunity to prove claims of impermissibly notivated discrimination.

2. Effect on Working Conditions. The proposition that non-sexually motivated gender discrimination nay be so "severe or pervasive as to alter the conditions" of einployment also appears to be an obvious one. Thus, the D.C. Circuit recognized im McKinney that "if a supervisor consistently uses physical force toward an eniployee because of that employee's sex, the use of such force inay, if pervasive enough, form an illegal "condition of employnient." "97 Courts should not assume that only sexual harassment can destroy employees' psychological well-being. "[T] he relevant legal question" is whether gender-motivated harassment, sexually motivated or not, is "sufficiently patterned or pervasive, [to] coinprise an illegal condition of employment under Title VII."98

Gender-based harassnient such as that engaged in by the hypothetical einployer above can clearly rise to this level. Analogies froin early hostile work environment cases in the context of racial, ethnic, and rehgious discrimination are again instructive on this point. In Calcote, for example, a supervisor constantly criticized an eniployee, ridiculed him, and harassed him in other ways. ${ }^{99}$ The court found that these acts of harassinent had such a serious impact on the employee's working conditions that he was forced to resign. ${ }^{100}$ The holding in Calcote is not, of course, unique. Many other decisions found that patterns of racial, ethnic, or religious harassment-bearing close sinilarities to the pattern of gender-based harassinent hypothesized above-were sufficiently severe intrusions on the work environment to violate Title VII. ${ }^{101}$

The determination of whether a pattern of gender-based harassment has a sufficiently serious impact on an employee's working conditions to violate Title VII is necessarily fact-specific. The important point here, as above, is that employees should be afforded an opportunity to prove that acts of gender-based harassment have been "severe or pervasive" intrusions on their work environments. The nature of an einployer's conduct,

96. Id. at 237.

97. McKinney, 765 F.2d at 1139.

98. Id. at 1138 .

99. 458 F. Supp. at 237. See supra text accompanying note 93.

100. Calcote, 458 F. Supp. at 237.

101. See Lucero v. Beth 1srael Hosp. and Geriatric Center, 479 F. Supp. 452, 454 (D. Colo. 1979) (black supervisor's continual harassment of non-black employees violates Title V1I); United States v. City of Buffalo, 457 F. Supp. 612, 632-35 (W.D.N.Y. 1978) (widespread and egregious racial harassment of blacks in city's police and fire departments violates Title VII); Compston v. Borden, Inc., 424 F. Supp. 157, 159 (S.D. Ohio 1976) (supervisor's constant harassment and verbal abuse of Jewish employee violates Title V1I). 
sexual or non-sexual, is not dispositive of the severity or pervasiveness of gender discrimination in the workplace.

\section{Current Judicial Treatment of Gender-Based HARASSMENT}

At present, it is simply not clear whether all courts recognize that gender discrimination in the workplace is actionable without regard to the presence of a sexual motive. The judicial treatment of allegations of gender-based harassinent has been both inconsistent and ambiguous. A basic division in the caselaw exists between decisions explicitly recognizmg that gender-based harassinent is actionable and decisions manifesting no such recognition. Unfortunately, both lines of authority present difficulties for einployees who are the victims of non-sexually motivated gender discrimination in the workplace.

Those decisions, such as Dwyer v. Smith, 102 which manifest no exphicit recognition that gender-based harassinent is actionable, have the most disturbing implications. Because such decisions are silent on the issue of whetlier gender-based harassinent is actionable, it is impossible to definitively determine those courts' views on the subject. However, an analysis of the reasoning in these cases suggests a tendency to seriously undervalue claims of gender-based harassment. Many courts view egregious sexual harassinent as the paradignı of a Title VII hostile work environment violation. ${ }^{103}$. When a hostile work environınent claim is predicated on acts of gender-based harassinent, these courts tend to find that such conduct has an insufficient effect on working conditions to violate Title VII. ${ }^{104}$ At best, such decisions simply obscure the availability

102. 867 F.2d 184 (4th Cir. 1989). See supra text accompanying notes 13-18.

103. See Scott v. Sears, Roebuck \& Co., 798 F.2d 210, 214 (7th Cir. 1986) (comparing plaintif's allegations to conduct involved in Meritor, Henson, and Bundy); Rabidue v. Osceola Refining Co., Inc., 805 F.2d 611 (6th Cir. 1986) (discussed infra text accompanying notes 130-42), cert denied, 481 U.S. 1041(1987); Miller v. Aluminum Co. of Am., 679 F. Supp. 495, 502 (W.D. Pa. 1988) (noting that explicit propositions, the use of sexual epithets, or offensive physical contact is generally required for a finding of a hostile work environment), aff'd, 856 F.2d 184 (3rd Cir. 1988); Wimberley v. Shoney's, Inc., 39 Fair Empl. Prac. Cas. (BNA) 444, 453 (S.D. Ga. 1985) (denying a hostile work environment claim, arguing that "[iln the three leading cases on sexually hostile working environments [Henson, Katz, Bundy], only shocking and pervasive sexually oriented misconduct amounted to a Title VII violation, not isolated incidents, mere epithets, or firtation.").

104. See Downum v. City of Wichita, 675 F. Supp. 1566, 1570 (D. Kan. 1986) (belittling and offensive comments directed to female firefighter comprise "fairly insignificant part of the total job environment"); Rabidue, 805 F.2d 611 (discussed infra text accompanying notes 130-42); Downes v. FAA, 775 F.2d 288 (Fed. Cir. 1985) (discussed infra note 147); Hallquist v. Max Fish Plumbing \& Heating Co., Inc., 46 Fair Empl. Prac. Cas. (BNA) 1855, 1860 (D. Mass. 1987) (evidence that plaintiff "was the subject of gender-related jokes and occasional teasing . . . when offered alone to establish a claim under a hostile work environment theory, is insufficient."), aff'd sub nom. Hallquist v. Local 276 Plumbers and Pipefitters Union, 843 F.2d 18 (1st Cir. 1988); Miller, 679 F. Supp. at 
of the hostile work environment remedy for gender-based harassment; at worst, they unduly restrict employees' statutory rights. To the extent that courts treat gender-based harassment as a relatively minor imtrusion on the work environment, they effectively render employers immune from hability for non-sexually motivated gender discrimination.

The second major category of caselaw consists of decisions expressly recognizing that gender discrimination in the work environment is actionable without regard to the presence of a sexual motive. Although recognition of this principle is, of course, a significant step, certain aspects of these decisions remain problematic. These decisions contimue to state that employees possess a cause of action for "sexual harassment." 105 In addition, these cases generally imvolve acts of gender-based harassment occurring in larger patterns of sexual harassment. ${ }^{106}$ The combination of these two factors may lead potential litigants to believe that they inust allege acts of sexual harassment in order to succeed on a hostile work environment claim. Thus, even tlese substantively correct decisions may not effectively render employers hable for gender-based harassment.

\section{A. Decisions Manifesting No Explicit Recognition that Gender-Based Harassment is Actionable}

1. Possible Rationales. Dwyer v. Smith, ${ }^{107}$ discussed in the imtroduction to this Note, ${ }^{108}$ rejected a feinale pohice officer's claim that lier employer had subjected her to a lostile work environment. The plaimtiff alleged that she was the victim of gender-motivated behavior that contamed sexual overtones, but did not allege that she was sexually harassed. ${ }^{109}$ Neither the district court nor the Fourth Circuit in Dwyer explicitly indicated whether it viewed the plaintiff's allegations as actionable under Title VII. Three explanations are possible for the conclusion

502 ('Snubs and unjust criticisms of one's work are not poisonous enough to create an actionable hostile work environment.").

105. See Hall v. Gus Const. Co., Inc., 842 F.2d 1010, 1013 (8th Cir. 1988); Hicks v. Gates Rubber Co., 833 F.2d 1406, 1413 (10th Cir. 1987); McKinney v. Dole, 765 F.2d 1129, 1131 (D.C. Cir. 1985) (describing action as one for "sex discrimination/sexual harassment").

106. See Hall, 842 F.2d at 1012 (female traffic controllers for construction company allege various acts of gender-based harassment along with allegations that male construction workers repeatedly requested sexual favors from them, exposed themselves, engaged in offensive physical touchings, and inflicted "verbal sexual abuse" on them); Hicks, 833 F.2d at 1409-10 (allegation of gender-based intimidation along with allegation of offensive physical touchings); McKinney, 765 F.2d at 1131 (allegation of use of force against female employee in context of allegations of "sexual advances and other sexual importunings" by male supervisors).

107. 867 F.2d 184 (4th Cir. 1989).

108. See supra text accompanying notes 13-18.

109. See supra text accompanying note 14 . 
reached by both courts that the plaintiff "failed to establislı a prima facie claim of sexual harassment": 110 (1) Both courts may have recognized that gender-based harassment is actionable, but simply have found that the plaintiff failed to prove her case; (2) both courts may lave viewed gender-based harassment as non-actionable under Title VII; (3) both courts may have viewed gender-based harassment as technically actionable, but as relatively insignificant.

Turning to the first possibility, the district court and the Fourth Circuit may have in fact recognized that gender discrimination in the workplace is actionable in the absence of a sexual motive, but simply failed to articulate that conclusion. Both courts may have ruled against Dwyer based on evidentiary insufficiency, believing either that her claims were untrue or that she did not establish that her employer's conduct rose to the level of a hostile work environment. In light of each court's focus on the existence of sexual harassment, however, this explanation is not compelling.

The statements of both courts regarding the evidence offered by Dwyer reveal a primary conceru with the existence of sexual harassment. In considering the plaimtiff's claims, the district court did find that Dwyer failed to establisli who sent certain of the mailings she received and also found that certain objectionable "art work" in the stationhouse was placed there by a female co-worker. ${ }^{111}$ However, the district court also apparently rejected certain claims of Dwyer because "no sexual langnage was ever directed at [her]; that only one of the inailings could be considered pornographic; ... and that two female police officers testified that sexual harassment did not exist in the [department]."112 The Fourth Circuit rehed on these findings and further noted that Dwyer liad not alleged any "suggestive behavior" on the part of her supervisor. ${ }^{113}$ The district court ultimately concluded that "[t]he only credible evidence that I find is that perliaps on occasion there has been inappropriate language and inappropriate references made to sex, but not harassment." 114

At the very least, the focus of these courts on sexual harassment injects significant ambiguity into their conclusions about the sufficiency of Dwyer's evidence. Did the district court mean that Dwyer was not harassed at all or did it mean that she was not sexually liarassed? Was her claim rejected because the character of the acts she complained of was not "sexual" or "suggestive" or because she did not prove that they

110. Dwyer, 867 F.2d at 188.

111. Id.

112. Id.

113. Id.

114. Id. 
had a significant effect on her working conditions? ${ }^{115}$ More significantly, however, the focus of both courts on sexual harassment and the lack of sexually motivated behavior strongly suggests that neither court viewed gender-based harassment as actionable per se. If derogatory terms were directed at Dwyer because she was a woman, if offensive and intimidating mailings were sent to her because she was a woman, or if her supervisors otherwise demeaned her because she was a woman, the absence of sexual content im these actions was entirely irrelevant. Any court that recognized the irrelevance of a sexual motive would have no reason to focus upon it so extensively.

If the district court and the Fourth Circuit did not view genderbased harassment as actionable per se, did they view it as entirely irrelevant under Title VII? A second explanation for the decisions in Dwyer is that neither court viewed the plaintiff's allegations of gender-based harassment as actionable. Although this account of the decisions is indeed plausible, it does not explam why either court discussed Dwyer's claims at length as opposed to simply dismissing the action.

The most plausible explanation of Dwyer is that the two courts viewed the plaintiff's allegations as actionable only insofar as they could be pigeonholed into the category of "sexual harassment." The Fourth Circuit began its account of Dwyer's action by stating, "[Plaintiff] contends that ... her work life has been rife with imruendo, disparagement, humiliation and insinuation-in short, sexual harassment."116 But Dwyer nowhere claimed that she was the victim 1 of sexual harassment. Not only did she not allege any sexually motivated behavior, but much of the "disparagement" and "humiliation" she claimed to have suffered was free even of sexual overtones. Nevertheless, the Fourth Circuit insisted on forcing Dwyer's claim under the rubric of "sexual harassment."

This explanation of Dwyer suggests that although both courts inay have viewed gender-based harassment as technically actionable, they also viewed it as relatively insignificant. Both courts appear to have treated sexual harassment as a powerful force capable of destroying an employee's psychological well-being. Gender-based harassment, even though "inappropriate," did not represent nearly as serious an invasion of an einployee's working conditions. Thus, Dwyer's allegation that her

115. The ambiguity in both opinions is further demonstrated by the Fourth Circuit's statement that, "[t]he district court rejected Dwyer's Title VII claim of sexual harassment, finding that she failed to present any evidence of sexual harassment that altered the conditions of her employment and created an abusive working environment." Id. at 187. It is simply not clear whether the court meant that Dwyer failed to present specific evidence of sexual harassment or that she failed to provide evidence of gender discrimination in general.

116. Id. at 187-88 (emphasis added). 
supervisor consistently treated her like a "problem child" was not as significant as would have been an allegation that he engaged in "suggestive behavior" toward her. ${ }^{117}$ It appears that because Dwyer's claims of humiliation and ridicule did not constitute sexual harassment, neither the district court nor the Fourth Circuit viewed these actions as capable of creating a hostile work environment. Dwyer's failure to allege sexually motivated behavior thus effectively deprived her of a remedy under Title VII.

\section{Sexual Harassment as the Paradigm of a Title VII Violation.} Many courts treat egregious sexual harassment as the paradigm of a Title VII hostile work environment violation. ${ }^{118}$ Thus, in Rabidue v. Osceola Refining Co., 119 the most influential hostile work environment case decided since Meritor, the Sixth Circuit viewed "sexual propositions, offensive touchings, [and] sexual conduct of a similar nature . . . systematically directed to the plamtiff over a protracted period of time" as a standard against which to evaluate claims of gender discrimination in the workplace. ${ }^{120}$ The Sixth Circuit's focus on conduct of a sexual nature was primarily a product of its reliance on two sources: the fact patterns of such leading decisions as Bundy v. Jackson, ${ }^{121}$ Henson v. City of Dundee, 122 and Katz v. Dole, ${ }^{123}$ and the EEOC Guidelines on Discrimmation Because of Sex. 124

Rabidue concerned a claim by a female employee at the Osceola Refining Company that she was subjected to a hostile work environment on the basis of her gender. The plaintiff, Vivienne Rabidue, alleged that one of the company's supervisors, ${ }^{125}$ Douglas Henry, continually inade obscene comments about women and sometimes directed these com-

117. Id. at 188.

118. See Scott v. Sears, Roebuck \& Co., 798 F.2d 210, 214 (7th Cir. 1986) (comparing plaintiffs allegations to conduct involved in Meritor, Henson, and Bundy); Rabidue v. Osceola Refining Co., Inc., 805 F.2d 611 (6th Cir. 1986) (discussed infra text accompanying notes 130-42); Miller v. Aluminuin Co. of Am., 679 F. Supp. 495, 502 (W.D. Pa. 1988) (noting that explicit propositions, the use of sexual epithets, or offensive physical contact is generally required for a finding of a hostile work environment); Wimberley v. Shoney's, Inc., 39 Fair Einpl. Prac. Cas. (BNA) 444, 453 (S.D. Ga. 1985) (court denies a hostile work environment claim, arguing that "[i]n the three leading cases on sexually hostile working environments [Henson, Katz, Bundy], only shocking and pervasive sexually oriented inisconduct amounted to a Title VII violation, not isolated incidents, mere epithets, or flirtation.").

119. 805 F.2d 611 (6th Cir. 1986).

120. Id. at 622 n.7.

121. 641 F.2d 934 (D.C. Cir. 1981). See supra text accompanying notes 56-62.

122. 682 F.2d 897 (11th Cir. 1982). See supra text accompanying notes 63-65.

123. 709 F.2d 251 (4th Cir. 1983). See supra note 19.

124. 29 C.F.R. $\$ 1604.11$ (1988).

125. Henry exercised no supervisory authority over the plaintiff, but her duties required her to work with him. Rabidue, 805 F.2d at 615. 
ments at her. ${ }^{126}$ Henry "regularly spewed anti-female obscenity" and "routinely referred to women as 'whores,' 'cunt,' 'pussy' and 'tits." "127 He also remarked of the plaintiff, "All that bitch needs is a good lay" and referred to her as "fat ass." 128 The plaintiff further contended that she was exposed to posters of nude women displayed by other male employees. ${ }^{129}$ The Sixth Circuit found that this conduct was not sufficiently mvasive of the plaintiff's working conditions to create an actionable hostile work environment and affirmed the district court's entry of summary judgment for the defendant. ${ }^{130}$

a. Reliance on leading decisions on gender discrimination in the work environment. In Rabidue, the Sixth Circuit coinpared the facts alleged by the plaintiff to the facts alleged im Bundy, Henson, and Katz and concluded that " $[t]$ he precedential cases addressing a sexually hostile and abusive environment . . . have all developed more compelling circumstances than are presented herein."131 The court stated:

In the case at bar, the charges of sexually hostile and abusive environment were limited to pictorial calendar type office wall displays of semi-nude and nude females and Henry's off-color language. Unlike the facts of Bundy, Henson, and Katz, this case involved no sexual propositions, offensive touchings, or sexual conduct of a similar nature that was systematically directed to the plaintiff over a protracted period of time. ${ }^{132}$

This mode of analysis is not unique to the Sixth Circuit ${ }^{133}$ and niay well be repeated by other courts seeking to define the scope of the hostile work environment.

In Rabidue, the Sixth Circuit rehed not only on the facts of Henson, but also on the test that the Eleventh Circuit set forth to evaluate the

126. $I d$.

127. Id. at 624 (Keith, J., concurring in part and dissenting in part) (citing district court's opinion, Rabidue v. Osceola Refining Co., Inc., 584 F. Supp. 419, 423 (E.D. Mich. 1984)).

128. Id. Apparently, the company did not deny that Henry engaged in such conduct. The majority referred to Henry as "an extremely vulgar and crude individual who custonnarily made obscene comments about women generally, and, on occasion, directed such obscenities to the plaintiff." Id. at 615. The company had inade unsuccessful efforts to curb Henry's conduct. Id.

129. Id. The dissent pointed out that one poster which was displayed for the entire seven years the plaintiff worked at Osceola "showed a prone woman who had a golf ball on her breasts with a man standing over her, golf club in hand, yelling 'Fore.' And one desk plaque declared 'Even male chauvinist pigs need love.' " Id. at 624 (Keith, J., concurring in part and dissenting in part).

130. Id. at 622. See infra text accompanying notes 148-51.

131. Rabidue, 805 F.2d at 622 n.7.

132. Id.

133. See Scott v. Sears, Roebuck \& Co., 798 F.2d 210, 214 (7th Cir. 1986); Wimberley v. Shoney's, Inc., 39 Fair Empl. Prac. Cas. (BNA) 444, 453 (S.D. Ga. 1985). 
plaintiff's allegations of a hostile work environinent. ${ }^{134}$ The test consists of five eleinents, one of which is proof of sexual harassinent. The Eleventh Circuit stated in Henson that the plaintiff needed to prove the following elements to establish her claim: (1) The employee belongs to a protected group; (2) The employee was subjected to unwelcome sexual harassinent; (3) The harassment complained of was based upon sex; (4) The harassment complained of affected a "term, condition, or privilege" of einployment; and (5) [where harassment is by a co-worker or supervisor] Respondeat superior. ${ }^{135}$

It is likely that courts faced with hostile work environment actions based on claims of gender discrimination will rely on the fact pattern of Meritor as well as the fact patterns of Bundy, Henson, and Katz. The action in Meritor, like the actions $\mathrm{m}$ those cases, presented allegations of egregious sexual harassment, mcluding a claim of rape. ${ }^{136}$

All of these sources-the fact patterns of Bundy, Henson, Katz, and Meritor, and the five-part test set out in Henson-create the impression that evidence of sexual misconduct is a prerequisite for a hostile work environment action. ${ }^{137}$ The holdings in these cases, however, derive froin the broad primciple that all discrinmation on the basis of an einployee's gender that is sufficiently "severe or pervasive to alter the conditions of einployinent" is actionable. 138 Indeed, Meritor states the broad proposition that "a plaintiff may establish a violation of Title VII by proving that discrimination based on sex has created a hostile or abusive work environment."139 To the extent that courts rely on the facts of these cases rather than their rationales, they will tend to artificially restrict the hostile work environment action to claims of egregious sexual harassment and to assign hittle weight to claims of gender-based discrimination.

b. EEOC Guidelines. The Sixth Circuit in Rabidue also cited the EEOC Guidelines as a "source of instruction to assist its efforts to probe the paraineters" of the hostile work environment action. ${ }^{140}$ The Guide-

134. Rabidue, 805 F.2d at 619-20; see also Downes v. FAA, 775 F.2d 288, 292-95 (Fed. Cir. 1985) (applying same test).

135. Henson v. City of Dundee, 682 F.2d 897, 903-05 (11th Cir. 1982).

136. See supra text accompanying note 11 .

137. At least one commentator has noted the potential for confusion regarding the scope of the hostile work environment action created by the fact pattern in Meritor. Hipp, Now You See It, Now You Don't: The "Hostile Work Environment" After Meritor, 26 AM. Bus. L. J. 339, 340 (1988) ("[t]he factual context of Meritor does not seem to be representative of the typical claims based on environmental factors").

138. Meritor Sav. Bank v. Vinson, 477 U.S. 57, 66 (1986).

139. Id. at 67 .

140. Rabidue, 805 F.2d at 619. 
lines, promulgated in 1980 , have been extremely influential in the judicial construction of the scope of the hostile work environment. ${ }^{141}$ The Guidelines provide:

Harassment on the basis of sex is a violation of Sec. 703 [now section 2000e-2(a)(1)] of Title VII. Unwelcome sexual advances, requests for sexual favors, and other verbal or physical conduct of a sexual nature constitute sexual harassment when (1) submission to such conduct is made either explicitly or implicitly a term or condition of an individual's employment, (2) submission to or rejection of such conduct by an individual is used as the basis for employment decisions affecting such individual, or (3) such conduct has the purpose or effect of unreasonably interfering witl an individual's work performance or creating an intimidating, lostile, or offensive working environment. ${ }^{142}$

In Rabidue, the Sixth Circuit interpreted the last sentence of the Guidelines as requiring the plaintiff to prove that "she had been subjected to unwelcomed verbal conduct and poster displays of a sexual nature" in order to prevail on her hostile work environment claim. ${ }^{143}$

The language of the EEOC Guidelines contributes to the impression of many courts that egregious sexual harassment is the paradigm of a Title VII hostile work environment violation. Although the Guidelines begim with the broad proposition that."harassment on the basis of sex" violates Title VII, they offer only one example of such conduct-sexual harassment. Section 1604.11(a) does not, of course, exphicitly state that "sexual harassinent" is the only form of "harassment on the basis of sex." The section, however, defines only "sexual harassment" and gives no indication that it is merely one form of "harassment on the basis of sex" or that other forins of "harassment on the basis of sex" may contribute to the creation of a hostile work environment. Thus, the Sixth Circuit's interpretation of the Guidelines in Rabidue was unfortunately quite reasonable.

Courts may perceive "unwelcome sexual advances, requests for sexual favors, and other verbal or physical conduct of a sexual nature" referred to in the Guidelines as relatively identifiable and may thus accept without challenge the notion that such conduct is a proper standard for evaluating hostile work environment actions. However, "an EEOC regulation that identifies certain activities as prohibited by Title VII [should not] be taken to mean that any other activities are allowed." 144 Moreover, the Supreme Court's language in Meritor provides a clear indication that the hostile work environment action apphes to the entire

141. For example, Justice Rehnquist relied heavily on the Guidelines in Meritor. 477 U.S. at 65.

142. 29 C.F.R. $\$ 1604.11$ (a) (1988).

143. 805 F.2d at 622 (emphasis added).

144. McKinney v. Dole, 765 F.2d 1129, 1139 n.20. (D.C. Cir. 1985). 
spectrum of gender discrimination in the workplace. ${ }^{145}$ Courts should not repeat the Sixth Circuit's mistake in Rabidue by limiting the remedy to egregious sexual liarassment.

\section{Insufficient Effect on Working Conditions. Courts frequently} reject hostile work environment claims predicated on acts of genderbased harassment on the basis that such conduct has not had a sufficiently serious effect on a plaintiff's working conditions to be actionable. ${ }^{146}$ These decisions often find that an employer's conduct is not so "severe or pervasive as to alter the conditions" of employment. ${ }^{147}$ Although such decisions may in many cases be accounted for by failures of proof, they also may be the products of courts' attitudes toward gender-based harassinent. These decisions often appear to reflect inadequate consideration of the dainage that gender-based harassinent can cause to an employee's psychological well-being. While courts unquestionably view sexual liarassment as capable of imposing a severe injury on einployees, it is less clear that they appreciate the potential for adverse effects caused by gender-based harassinent.

145. The Supreme Court noted in Meritor that while the Guidelines are helpful for construing the scope of Title VII, they are "not controlling upon the courts by reason of their authority." 477 U.S. at 65 (quoting General Elect. Co. v. Gilbert, 429 U.S. 125, 141 (1944)).

146. See Downum v. City of Wichita, 675 F. Supp. 1566, 1570 (10th Cir. 1986) (belittling and offensive comments directed to female firefighter comprise "fairly insignificant part of the total job environment"); Rabidue v. Osceola Refiming Co., Inc., 805 F.2d 611 (6th Cir. 1986) (discussed infra text accompanying notes 148-51); Downes v. FAA, 775 F.2d 288 (Fed. Cir. 1985) (discussed infra note 147); Hallquist v. Max Fish Plumbing \& Heating Co., 46 Fair Empl. Prac. Cas. (BNA) 1855, 1860 (D. Mass. 1987) ("evidence [that plaintiff] was the subject of gender-related jokes and occasional teasing ... when offered alone to establish a claim under a hostile work environment theory is insufficient"); Miller v. Aluminum Co. of Am'., 679 F. Supp. 495, 502 (W.D. Pa. 1988) ("Snubs and unjust criticisms of one's work are not poisonous enough to create an actionable hostile work environment").

147. See Downes v. FAA, 775 F.2d 288 (Fed. Cir. 1985). In Downes, the Federal Aviation Administration charged an aviation safety inspector with sexual harassinent on the basis of the following conduct: (1) referring to a female employee as "the Dolly Parton of the office" in a conversation with a third person; (2) speculating in a telephone conversation with the einployee on the frequency of her sexual relationships after her divorce; (3) touching the employee's laair twice; (4) asking the elnployee whether she ever considered trading sexual favors to get ahead in the agency and stating, "Boy, if I had a body hike yours, I'd really go places;" and (5) repeating in the office a Bob Hope joke about women in tight shorts. The Federal Circuit reversed a decision of the Merit Systems Protection Board which had sustained the charges against the inspector. The court found that this conduct was not "sufficiently severe or persistent" to constitute a hostile work environinent:

Even discounting the trivial nature of some incidents, these few instances, which we assume to have occurred, do not establish a pattern of harassment directed to "feinale employees" or to a particular employee. They do not sliow that conduct has been repcated to the point where it is "routine" or "of a generalized nature," i.e., lias become a "condition" of anyone's employinent.

Id. at 294. 
Rabidue demonstrates an apparent lack of sensitivity to the capacity of gender-based harassment to destroy an employee's psychological wellbeing. The Sixth Circuit held that the obscemties and poster displays at issue in Rabidue were not sufficiently serious to create a hostile work environment. ${ }^{148}$ The court found that:

Henry's obscenities, although annoying, were not so startling as to have affected seriously the psyches of the plaintiff or other female en1ployees. The evidence did not denionstrate that this simgle employee's vulgarity substantially affected the totality of the workplace. The sexually oriented poster displays had a de minimis effect on the plaintiff's work environment when considered in the context of a society that condones and publicly features open displays of written and pictorial erotica at the newsstands, on prime-time television, at the cimema, and in other public places. ${ }^{149}$

Although the facts of Rabidue provide some justification for the view that Henry's conduct did not affect "the totality of the workplace,"150 these facts do not appear to have been the basis of the Sixth Circuit's opinion.

The Sixth Circuit, rather, appears to have demed the plaintiff's claims on the basis of questionable assumptions about the effects of Henry's obscemities and the poster displays. The court, as noted above, ${ }^{151}$ described Henry's vulgarities as "off color language." This description is quite shocking given the nature of the terms he employed when referring to women. The court additionally described Henry's obscenities as "annoying," but not "startling." This claim is hardly compelling. It is unlikely that employees who were subjected to Henry's tirades-who were called "whores" by their supervisor-viewed these obscenities as mild intrusions on the workplace. Finally, the Sixth Circuit appears to have assumed that because "pictorial erotica" is commonplace, it could not constitute part of a pattern of offensive working conditions. However, as Judge Keith noted in dissent: "The presence of pin-ups and misogynous language in the workplace can only evoke and confirm the debilitating norms by which women are primarily and contemptuously valued as objects of male sexual fantasy."152

If Title VII is to provide an effective remedy for the entire spectrum of gender discrimination in the workplace, courts must be sensitive to the potential of all forms of gender discrimination to destroy an employee's

148. Rabidue, 805 F.2d at 622 .

149. Id.

150. For example, Henry was not the plamtiff's supervisor and she apparently did not have to work with him on a daily basis. Id. at 615 .

151. See supra text accompanying note 132.

152. Id. at 627 (Keith, J., concurring in part and dissenting in part). 
psychological well-being. To the extent that courts assign diminished weight to allegations of gender-based harassment, they artificially restrict the scope of the hostile work environment action.

\section{B. Decisions Explicitly Recognizing Gender-Based Harassment as Actionable}

1. Mischaracterization of Claims as Actions for "Sexual Harassment." A number of courts have exphicitly recognized that gender discrimination $\mathrm{m}$ the workplace is actionable without regard to the presence of a sexual motive. ${ }^{153}$ Despite their unquestionable recognition of this principle, these courts have articulated their conclusions in a manner that potentially obscures the availability of Title VII as a remedy for gender-based harassment. First, these courts continue to describe the hostile work environment claim in the gender discrimination context as an action for "sexual harassment."154 Second, despite the broad holdings of these cases, most of these opinions deal with isolated acts of genderbased harassment that occur within larger patterns of sexual harassment. ${ }^{155}$

In Hall v. Gus Construction Co., 156 the Eighth Circuit recognized that gender discrimination in the work environment is actionable regardless of whether it is sexually motivated. Hall involved a claim by three female employees of a construction company that their supervisors and co-workers subjected them to persistent discriminatory treatınent. The pattern of abuse alleged by these employees included certain acts of gender-based harassment: references to one plaintiff as "Herpes" because of a skin condition; male crew members urinating im the gas tank of another plaimtiff's car (characterized as a practical joke); and the company's failure to fix certain equipment while female employees were operating it. The plaintiffs also alleged acts of sexual harassment, contending that male construction workers repeatedly requested sexual favors, exposed themselves to the women, engaged in offensive physical touchings, and inflicted "verbal sexual abuse" on the plaintiffs. 157

153. See Hall v. Gus Constr. Co., 842 F.2d 1010 (8th Cir. 1988); Hicks v. Gates Rubber Co., 833 F.2d 1406 (10th Cir. 1987); McKinney v. Dole, 765 F.2d 1129 (D.C. Cir. 1985); Bell v. Crackin Good Bakers, 777 F.2d 1497 (11th Cir. 1985).

154. See Hall, 842 F.2d at 1013; Hicks, 833 F.2d at 1408; McKinney, 765 F.2d at 1131 (describing action as one for "sex discrimination/sexual harassment").

155. See Hall, 842 F.2d at 1012 (discussed infra text accompanying notes 156-61); Hicks, 833 F.2d at 1409-10 (allegation of gender-based intinidation along with allegation of offensive physical . touchings); McKinney, 765 F.2d at 1131 (allegation of use of force against female employee in context of allegations of "sexnal advances and other sexnal importunings" by inale supervisors).

156. 842 F.2d 1010 (8th Cir. 1988).

157. Id. at 1012. 
The employer argued that only "conduct of a sexual nature" was relevant to a hostile work environment action and complained that the district court had improperly considered evidence of non-sexual incidents in assessing the plaintiffs' claim. ${ }^{158}$ The Eighth Circuit held that the district court's consideration of these incidents was proper. ${ }^{159}$ The court of appeals reasoned that "[i]ntimidation and hostility toward women because they are women can obviously result from conduct other than explicit sexual advances."160 Judge Wollman articulated the somewhat paradoxical conclusion that "the predicate acts underlying a sexual harassment claim need not be clearly sexual in nature." 161 Thus, although the Eighth Circuit clearly recognized that gender discrimination in the work environment is actionable even in the absence of a sexual motive, it defined the plaintiff's action as a "sexual harassinent claim."

The Eighth Circuit's characterization of the claim in Hall as one for "sexual harassment" presents a semantic problem. The plaintiff's claim was not in fact limited to allegations of sexual harassment. More importantly, however, this characterization creates confusion as to the true scope of employees' rights under Title VII. To the extent that the plaintiffs did present allegations of sexually motivated behavior, the court had an independent basis upon which to conclude that all of the defendants' conduct, even that which was not sexual in nature, was inotivated by gender. ${ }^{162}$ Potential hitigants thus could reasonably beheve that a "sexual harassment claim" requires them to allege at least some instance of sexually motivated behavior. Such a perception would deter employees froin bringing hostile work environment actions founded solely on acts of gender-based harassment and wonld effectively render employers who create offensive working conditions on the basis of gender-but who do not sexually harass their workers-immune from hability under Title VII.

2. Gender-Based Harassment as the Sole Basis for a Hostile Work Environment Action. There is at least one decision, Bell v. Crackin Good Bakers, Inc., ${ }^{163}$ that appears to recognize that a pattern of genderbased harassment can by itself serve as the predicate for a hostile work

158. Id. at 1013.

159. Id. at 1014.

160. Id.

161. Id.

162. Id.; see also Hicks, 833 F.2d at 1409-10 (allegation of gender-based intimidation along with allegation of offensive physical touchings); McKinney, 765 F.2d at 1131 (allegation of use of force against female employee in context of allegations of "sexual advances and other sexual importunings" by male supervisors).

163. 777 F.2d 1497 (11th Cir. 1985). 
environment action. ${ }^{164}$ Although the crucial passage in Bell contains some confusing language, the Eleventh Circuit's opinion indicates that such a claim is cognizable under Title VII.

Bell involved a feinale employee's allegations that her iminediate supervisor (a male) undertook a dehiberate scheine to force her to resign. The plaintiff, Delores Bell, contended that her supervisor directed her to perform certain tasks and then criticized her for acting without authority to do so, yelled at her, assigned her numerous tasks at once, and treated her "like [she] was about two years old and two inches high."165 For purposes of considering the defendant's summary judgment motion, both the district court and the Eleventh Circuit accepted the plaintiff's allegations as true. ${ }^{166}$ The district court granted summary judgment for the defendant on these facts, finding no evidence that the supervisor "wantcd her to resign because she was female."167 The district court treated the action as one for "sexual harassment."168

On appeal, however, the Eleventh Circuit considered additional evidence that it beheved was capable of demonstrating that the supervisor's harassment was indeed motivated by gender. ${ }^{169}$ This evidence included testimony that the supervisor had stated that men were more effective workers than women, that he constantly belittled the plaintiff, and that he treated men who occupied the saine position in a different inanner than he treated Bell. ${ }^{170}$

The Eleventh Circuit found that the district court's treatment of the plaintiff's action as one for "sexual harassinent" was erroneous. ${ }^{171}$ The district court's characterization of the action was flawed because "[t]he plaintiff offered no proof of actions by [her inmediate supervisor] or by any other supervisory employee that would fall within the context of this

164. See also Bennett v. Corroon \& Black Corp., 845 F.2d 104, 106 (5th Cir. 1988) (noting that depiction of female employee in obscene cartoons $\mathrm{m}$ men's bathroom constitutes the "perfect matrix to grow the hostile work environment subjecting a woman to discriminatory intimidation, ridicule, and insult which Title VII protects against," but holding this act insufficiently "severe or pervasive" to violate the statute), cert. denied, 489 U.S. 1020 (1989).

165. Bell, 777 F.2d at 1499.

166. Id.

167. Id.

168. Id. at 1502.

169. Id. at 1501 ("It is evident that inferences could well be drawn from the totality of the evidence given on behalf of the petitioner that would support her contention that the employer was guilty of discriminating against her with respect to the conditions of her employment on the grounds of her sex.")

170. Id. at 1500 .

171. Id. at 1503 ("It is clear that the [district] court viewed the evidence offered by the plaintiff under the wrong standard.") 
Court's definition of 'sexual harassment." "172 The Eleventh Circuit followed the defimition of sexual harassment set forth in the EEOC Guidelines, which encompasses only "conduct of a sexual nature."173

The court of appeals indicated that the plaintiff's claim was one for "sexual/gender discrimination." 174 It identified the McDonnell Douglas Corp. v. Green ${ }^{175}$ franework as the appropriate method to determine whether the plaintiff had been subjected to unequal treatment because of her sex and squarely held that Bell was "under no obligation to adduce proof of 'sexual advances, requests for sexual favors [or] other verbal or pliysical conduct of a sexual nature." "176 The plamtiff thus could establish the existence of discrimination "because of sex" simply on the basis of her supervisor's apparent chauvinism and general hostility toward women.

The Eleventh Circuit appears to have recognized that the predicate acts for a hostile work environment action need not be sexual in nature. After discussimg the lostile work environment claim at length and quoting from Rogers v. EEOC, 177 the court stated: "Such harassment can be of at least two kinds: (1) a threatening, bellicose, demeaning, hostile or offensive conduct by a supervisor in the workplace because of the sex of the victim of such conduct; or (2) 'unwelcome sexual advances' generally known as a 'quid pro quo' ground."178 Bell's case clearly fits only the first category. To the extent that the Eleventh Circuit reversed the district court's grant of summary judgnient and allowed Bell to proceed with her claim, it recognized that "threatening, bellicose, demeaning, hostile or offensive conduct by a supervisor in the workplace because of the sex of the victim of such conduct" encompasses harassment that is entirely free of sexual content. The net effect of Bell was to allow a plaintiff who brought a hostile work environment action founded solely on gender-based harassment the opportunity to prove lier case.

172. Id. at 1502. The court also stated that "[t]he complaint made no contention of 'sexual harassment' in the context of the Henson case". Id.

173. See supra text accompanying note 142 .

174. Id. at 1502 .

175. 411 U.S. 792 (1973). See supra text accompanying note 89.

176. Bell, $777 \mathrm{~F} .2 \mathrm{~d}$ at 1503.

177. 454 F.2d 234 (5th Cir. 1971).

178. Bell, 777 F.2d at 1503 . The ambiguity in Bell arises because it is unclear precisely to what the phrase "[s]uch harassment" refers. It appears to refer to "[s] exual harassment which creates a hostile or offensive environment," a phrase used in the immediately preceding paragraph. However, the court probably used the phrase "[s] uch harassment," more broadly to refer to harassment sufficient to constitute a hostile work environment. This interpretation is certainly plausible given that the first category delineated by the court clearly contains no requirement of conduct of a sexual nature. 


\section{CONCLUSION}

Title VII is aimed at eliminating gender discrimination that affects the "terms, conditions, and privileges" of einployinent. If courts are willing to characterize an einployee's psychological well-being as a protected condition of einployment, then they should not place arbitrary restrictions on the protection of that condition. Title VII proscribes all gender discrimination that is sufficiently intrusive on an employee's psyche. There is no rationale for restricting the statute's application to only sexually motivated discrimination that poisons the work environment. Unequivocal recognition of gender-based harassinent as a viable predicate for a hostile work environment action is necessary to give employees a reinedy for the entire spectrum of gender discrimination in the workplace.

Recognition that gender discrimination in the workplace is actionable without regard to the presence of sexual motives has potentially farreaching imphications. The hostile work environinent claim makes actionable an extreinely broad and ill-defined range of conduct. It will be difficult for einployers to predict what types of conduct constitute "intimidation" or "humiliation" forbidden by Title VII. In order to avoid violating the statute, einployers inay be forced to restructure the way they think about female einployees by carefully considering the motives behind their treatment of women.

The seemingly broad inplications of this Note inerely highlight the extent to which gender discrimination is ingrained in the workplace. If gender-based harassinent is recognized as actionable, employers may wonder whether calling a female einployee, "Honey," or making sexist jokes will lead to hability under Title VII. It is doubtful, however, whether einployers have much question about whether calling black employees, "Boy," or making racist jokes, if sufficiently patterued, will lead to such liability. Arguably, the difference is that sexist behavior is perceived as relatively more acceptable, or as relatively less offensive, than racist behavior in the workplaces of America. Title VII should not countenance this perception.

Although the implications of recognizing gender-based harassment as actionable are clearly very broad, liniting principles exist within current hostile work environment jurisprudence. Gender-based harassment must be "severe or pervasive" in order to be actionable. This test, if properly applied, ensures that not every utterance of the term "Honey" and not every sexist joke is actionable. The problem with the current judicial application of the "severe or pervasive" test is one of inadequate appreciation of the harm that gender-based harassment can cause. If rec- 
ognition of gender-based harassment as actionable is to have any real effect in the workplace, courts must apply this standard in a non-sexist fashion.

Finally, the current judicial focus on sexual harassment is obviously commendable because it redresses very serious injuries. This focus, however, also has the negative effect of restricting the types of gender discrimination for which female employees have a remedy. The ability of woinen to remedy all forms of gender discrimination that affect their working conditions will be of increasing concern as women contimue to enter the work force in larger numbers. The hostile work environment action can be an important tool im the effort to eradicate barriers to equal opportumity in the workplace.

Joshua F. Thorpe 